\title{
Single Blind Placebo Controlled Study of Herbs
}

Shah Murad, HOD ${ }^{*}$, Khalid Niaz AP ${ }^{2}$, Manal Raouf Mahar ${ }^{3}$, Palwasha Awan ${ }^{4}$, Abrar Hussain Azad, HOD ${ }^{5}$, Sibghatullah Sangi ${ }^{6}$

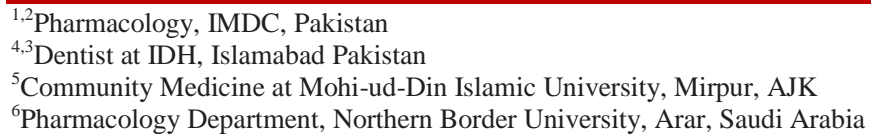

Allium cepa (onion) and Zingiber officinale (ginger) has antioxidant feature so are in dyslipidemia in primary and secondary hyperlipidemia and prevent CAD in human body. Hypolipidemic drugs used in allopathy include Statins, Fibric acids, Niacin, and Resins but all have their low compliance due to frequent side effects. Medicinal herbs like Onion and Ginger are hypolipidemic agents commonly used as flavoring agents and making foods spicy and tasty. We have compared hypolipidemic potential between these two medicinal herbs. The study was conducted at Ghurki Trust teaching hospital, Lahore from January to June 2016. Eighty secondary hyperlipidemic patients were enrolled after getting written consent which was approved by Ethics committee of the hospital. They were divided in two equal groups comprising 40 patients in each group. Group-I was treated by Ginger 10 grams daily in three divided doses for 2 months. Group-II was advised to take Onion 200 grams daily in divided amount with each meal i.e.; breakfast, lunch, and dinner for two months. After two months therapy it was observed by statistical analysis that 10 grams ginger reduced TC (total cholesterol) of 38 hyperlipidemic patients $12.4 \mathrm{gm} / \mathrm{dl}$ and LDL-C (low density lipoprotein cholesterol) $27.3 \mathrm{mg} / \mathrm{dl}$. In group-II, onion reduced TC in 35 patients $17.9 \mathrm{mg} / \mathrm{dl}$ and LDL-C $14.8 \mathrm{mg} / \mathrm{dl}$. Changes in tested parameters are significant biostatistically with p-values $<0.01$ to $<0.001$. We concluded from this research work that Onion and Ginger reduces risk of CAD by decreasing plasma total cholesterol and LDL cholesterol.

Keywords: Placebo, Herbs, Placebo.

Copyright $\odot 2020$ The Author(s): This is an open-access article distributed under the terms of the Creative Commons Attribution 4.0 International License (CC BY-NC 4.0) which permits unrestricted use, distribution, and reproduction in any medium for non-commercial use provided the original author and source are credited.

\section{INTRODUCTION}

If someone considers about metabolic syndrome, it obviously applies to dyslipidemia, hyperglycemia, and hypertension, all of these conditions lead to formation of atherosclerotic plaques which are deposited to interior wall of coronary arteries causing CAD [1]. Complications of CAD include CCF, cardiac arrhythmias, and heart attack [2, 3]. Metabolic syndrome is complicated to treat by medicines combination therapy including hypoglycemic, hypolipidemic, and hypotensive agents $[5,6]$. Allopathic drug regimens used in metabolic syndrome have low patients compliance due to their life long utilization and from mild to severe side effects [7]. Look at only hypolipidemic allopathic agent's side effects. Statins and Fibrates causes' rhambomyolysis (muscular dystrophy) causing muscular pain, Niacin causes flushing resembling to allergic reactions and Resins which are difficult to use for prolonged period due to their metallic taste, and stomach bloating [8].
Medicinal herbs are alternative therapeutic agents with no or very less frequency, and intensity of side effects. For example onion and ginger are used in various food recipes. These two agents have been proved scientifically as hypolipidemic characteristics [9, 10]. Allium cepa (onion) byproduct contains factors with the ability to modulate plasma lipids and lipoprotein levels. High in vitamin $\mathrm{C}$, onions are a good source of dietary fiber, and folic acid. They also contain calcium, iron, and have a high protein quality. Onions are low in sodium and contain no fat. Onions contain quercetin, a flavonoids; one category of antioxidant compounds [1113]. Antioxidants are compounds that help delay or slow the oxidative damage to cells and tissue of the body [14]. Studies have indicated that quercetin helps to eliminate free radicals in the body, to inhibit lowdensity lipoprotein oxidation which is an important reaction in the atherosclerosis and coronary heart disease. It also protects and regenerates vitamin $\mathrm{E}$, which is a powerful antioxidant. It also inactivates the harmful effects of chelate metal ions [15-17]. At least 
115 constituents in fresh and dried Zingiber officinale (ginger) varieties have been identified by a variety of analytical processes [18]. Zingiber officinale contains antioxidant compounds like gingerols, shogaol, and paradols. Gingerol inhibits nitric oxide synthesis in activated macrophages and prevents peroxynitriteinduced oxidation and nitration reactions. Peroxynitrite induces DNA base damage predominantly at guanine (G) and 8-oxoguanine (8-oxoG) nucleobases via oxidation reactions [19]. Ginger roots contain carbohydrates, sugars, dietary fibers, fat, protein, vitamin $\mathrm{B} 1,2,3,5,6,9$, vitamin $\mathrm{C}$ and vitamin $\mathrm{E}$. It also contains calcium, iron, magnesium, manganese, phosphorous, potassium, sodium, and zinc [20, 22].

\section{MATERIAL AND METHOD}

Ghurki Trust Teaching Hospital Lahore, Pakistan was place of studyand research was conducted from January 2016 to June 2016. Eighty newly diagnosed secondary hyperlipidemic patients were selected with age range from 20 to 60 years. Exclusion criteria were peptic ulcer, any gastrointestinal upset, hypothyroidism, diabetes mellitus, renal impairment, and patients suffering from any liver or heart disease. All patients were divided in three equal numerical groups i.e.; 25 in each group. Their baseline vital organ function's data were taken at start of research work i.e.; lipid profile, blood pressure and pulse rate. The study period was sixty days. Forty patients of group-I were advised to take Ginger 10 grams daily in divided amount with each meal for two months. Forty patients of group-II were advised to take 200 grams Onion daily as salad with breakfast, lunch and dinner for 2 months. Fortnightly follow-up visit was advised to all patients. They were also advised not to take fast or junk food for two months of research study duration. Drug compliance to the regimen was monitored by interview and counseling at each follow-up visits. Serum LDLcholesterol was calculated by Friedwald formula (LDLCholesterol $=$ Total Cholesterol-(Triglycerides $/ 5$ + HDL-Cholesterol). Data were expressed as the mean \pm SD and " $t$ " test was applied to determine statistical significance as the difference. A probability value of $<0.01$ was considered as significancant and $\mathrm{P}<0.001$ was considered as highly significant change in the parameter tested in study.

\section{RESULTS}

Results of study are shown in following table. After two months treatment of eighty hyperlipidemic patient's lipid profile's changes before and after treatment were analyzed biostatistically. In group-I two patients discontinued drugs, and in Group-II five patients withdrew from the study due to low compliance of herbs or due to their personal problems. Mean values with \pm SD before and after treatment are shown in following table with their p-values in Statistical significance column.

\begin{tabular}{|l|l|l|l|l|l|}
\hline Group and parameters & At day-0 & At day-60 & Overall change & Change in \% & p-value \\
\hline GROUP-I n=38 & & & & & \\
TC & $269.13 \pm 3.10$ & $256.77 \pm 1.87$ & $12.4 \mathrm{mg} / \mathrm{dl}$ & 4.6 & $\mathrm{p}<0.01$ \\
LDL-C & $177.64 \pm 2.02$ & $150.32 \pm 1.98$ & $27.3 \mathrm{mg} / \mathrm{dl}$ & 15.4 & $\mathrm{p}<0.001$ \\
\hline GROUP-II n=35 & & & & & \\
TC & $287.33 \pm 2.00$ & $269.44 \pm 3.01$ & $17.9 \mathrm{mg} / \mathrm{dl}$ & 6.2 & $\mathrm{p}<0.01$ \\
LDL-C & $203.17 \pm 2.22$ & $188.42 \pm 1.85$ & $14.8 \mathrm{mg} / \mathrm{dl}$ & 7.3 & $\mathrm{p}<0.01$ \\
\hline
\end{tabular}

$\mathrm{TC}=$ group $-\mathrm{I}=$ ginger, Group-II $=$ Onion. Total cholesterol, LDL-C $=$ low density lipoprotein cholesterol, $\mathrm{n}=$ sample size. \pm indicates

SEM. P-values $<0.01=$ significant change in the parameter. $\mathrm{P}$-value $<0.001=$ highly significant changes in the tested parameters

\section{DISCUSSION}

Cardiovascular problems in human population are mainly related with acquired facts like sedentary life style, smoking, alcohol use, utilization of drugs without prescription, and high intake of junk foods [23]. Elevated oxidant stress linked to pro-inflammatory conditions contributes to the development of alterations in the bioavailability of vascular nitric oxide and some endothelial cell dysfunctions that can culminate in profound impairments to vascular reactivity [24]. Low density lipoproteins in plasma will be oxidized, if there is burden of reactive oxygen species (ROS) in human body [25]. Atherosclerotic plaques leading to cause coronary artery disease is key factor for morbidity/mortality all over the world. To reduce hyperlipidemic state is essential step to decrease risk of CAD [26]. Allopathic hypolipidemic medicines are being replaced by herbal hypolipidemic agents due to wide range of pharmacological actions produced by allopathic drug regimens [27]. Ginger have had been used since long to treat gastrointestinal, respirac toy, skin, pulmonary, brain, heart diseases. Ginger root contains a very high level $(3.85 \mathrm{mmol} / 100 \mathrm{~g})$ of total antioxidants, surpassed only by pomegranate and some types of berries [28]. Ginger was reported to suppress TPA-induced oxidative stress in human promyelocytic leukemia [29]. In some research works it have been proved that ginger compounds effectively inhibit superoxide production [30]. Several reports indicate that ginger suppresses lipid peroxidation and protects the levels of reduced glutathione [31]. Ginger was reported to decrease age-related oxidative stress markers and was suggested to guard against ethanolinduced hepatotoxicity by suppressing oxidative consequences in rats treated with ethanol ${ }^{32}$. When we used 10 grams of ginger root in 38 hyperlipidemic patients, it reduced total cholesterol in plasma 12.4 $\mathrm{mg} / \mathrm{dl}$ and LDL cholesterol reduction was $27.3 \mathrm{mg} / \mathrm{dl}$ in two months. Same results were observed in study conducted by Makroue S et al. [33] who used ginger 
roots 12 grams daily in 49 hyperlipidemic patients for three months. Palisa V et al. [34] explained mechanism of action of ginger as antioxidant that it scanege free radicles in plasma due to its content ie; gingerol. Palisa $\mathrm{v}$ et al. [34] proved $13 \%$ decrease in TC, and $17 \%$ decrease in LDL cholesterol when they used 8 grams of ginger roots in 103 hyperlipidemic patients for six months. This mismatch in two studies may be due to large sample size and ingestion of drug used for long period. Recently, great attention has been focused on the role of the antioxidative defense system in oxidative stress. Endogeneous antioxidants in medicinal herbs may play an important role in antioxidative defense against oxidative damage, possibly protecting the biological functions of cells. There is increasing interest in the protective biological function of natural antioxidants contained 35]. Onion when we used in 35 hyperlipidemic patients it reduced plasma total cholesterol $17.9 \mathrm{mg} / \mathrm{dl}$, and LDL cholesterol $14.8 \mathrm{mg} / \mathrm{dl}$ in two months therapy. These results match with research study conducted by Mustavye J et al. [36] who proved almost same changes in these two parameters of lipid profile in 55 hyperlipidemic patients when they used 100 grams of onion for two weeks only. These results are in contrast with our results. May be the environmental factors change research study results. We restricted junk food to our patients and keep continue brisk walk for half an hour daily for the duration of study period. The antioxidant action of ginger has been proposed as one of the major possible mechanisms for the protective actions of the plant against a number of toxic agents such as carbon tetrachloride and cisplatin. Recently, it has been shown that 6-gingerol is endowed with strong anti-oxidant action both in vivo and in vitro, in addition to strong anti-inflammatory and anti-apoptotic actions [37]. Floreie C et al. [38] mentioned that numerous enzymatic and nonenzymatic mechanisms take place to protect the cell against oxidative damage. The radical chain reaction of lipid peroxidation appears to be a continuous physiological process. This process, if out of control, can alter essential cell functions and lead to cell death $^{39}$. Reactive oxygen species (ROS) can be detoxified by an enzyme defense system, comprising superoxide dismutase (SOD), catalase (CAT), and selenium-dependent glutathione peroxidase, or nonenzymatic systems by the scavenging action of GSH, while organic peroxides can be detoxified by the activity of glutathione S-transferase (GST) [40]. Onion contains phytochemicals that can increase detoxifying enzymes for ROS, but exact mechanaism is not known yet [41]. A group of volunteers fed a high fat diet plus $100 \mathrm{~g}$ onion once a day and those fed fat diet only showed a significant decrease in serum triglycerides, but not cholesterol, as compared to those only fed with fat diet only. Another study reported that oral administration of a butanol onion extract to patients with elementary lipemia prevented an increase in total serum cholesterol, Jlipoprotein cholesterol, and $\mathrm{J}$ lipoprotein and serum triglycerides. Gyvesta YF et al.
[42] described that quercetin (one of the content of onion) has been shown to have antioxidant activity related to a strong scavenging capacity. Various studies have had proved fundamental use of phytochemical to reduce risk for coronary artery diseases as mentioned by Noor M et al. [43]. Jan MM et al. [44] proved same effects of onion extracts used in rats and found this phytochemical quercetin (present in onion) as potent as statins as hypolipidemic agent. Fovuca $\mathrm{M}$ et al. [45] Jacob C et al. [46], Murad T et al. [47], and Sengv U et al. [48] explained that onion is natural antioxidant plant and it works as modulator of detoxification in human population.

\section{REFERENCES}

1. Duhallja B, Desaii R, Sookerva E, Anderson M, Bruckert, Eric; Labreuche, Julien; Amarenco, Pierre. Herbs have hypolipidemic effects but their wide range of pharmacological effects should be considered. JIU. 2014;23(5):666-8.

2. Rolukutta Ht, Jehanv TY, Magarr AA, Nomave GG, Sandhu MS, Day NE, Luben R, Bingham SA, Peters RJ, Wareham NJ, Khaw KT. Physical activity, C-reactive protein levels and the risk of future coronary artery disease in apparently healthy men and women: the EPIC-Norfolk prospective population study. Af J Comm Med. 2014;4(6):100103.

3. Lughar T, Nasdus T, Fulkarrh T, Furnoveya M, Kawaguchi K, Mizuno T, Aida K, Uchino K. Blood lipids and CAD. BSP. 2016;6(6):49-54.

4. Kultra C, Bekarh B, Saqalom B, Panchal SK, Poudyal H, Iyer A, Nazer R, Alam M.A., Diwan V., Kauter K., Sernia C., Campbell F., Ward L. High-carbohydrate, high-fat diet-induced metabolic syndrome and cardiovascular remodeling. J. Cardiovasc. Pharmacol. 2011;57:611-24.

5. Mosadi HH, Khushamad NN, Fikarnafa BY, Namaqul VT, Malook MB, Vareya TL, Saliha B, Sipahib T, Oybak Dönmez, E. Metabolic syndrome and antioxidant agents. JEB 2014;6(3):66-9.

6. Muatqadd G, Folika G, Jia G., Aroor A.R., Whaley-Connell A.T., Sowers J.R. Fructose and uric acid: Is there a role in endothelial function? Curr. Hypertens Rep. 2014;16:434.

7. Feela M, Kaluve N, Goto T, Teraminami A, Lee JY, Ohyama K, Funakoshi K, Kim YI. Drugs for metabolic syndrome and their complications. J Nutr Biochem 2012;23:768-76.

8. Fuqrawa S, Mittal MK, Florin T, Perrone J, Delgado JH, Osterhoudt KC. Allopathy related hypolipidemic drugs. Ann Emerg Med 2010;50(5):587-590.

9. Parasandve T, Faure P, Rossini E, Wiernsperger N, Jaiyawi U, Pawove T. Medicinal plants and its wastage. Diabetes. 2013; 48: 353-57.

10. Gaqavanyve Y, Assayed ME. Radioprotective effects of black seed (Nigella sativa) oil against hemopoietic damage and immunosuppression in 
gamma-irradiated

Immunotoxicol. 2010;32:284-296.

11. Kunitomo M. Oxidative stress and atherosclerosis treated by onion. J Phytoch. 2010;127(12):199-206.

12. Lompara BT, Capuzzi DM, Morgan JM, Brusco $\mathrm{OA}$, Intenzo CM. Indian Onion is the best: Hypercholesterolemia. Curr Atheroscler Rep 2010;2(1):64-71.

13. JB Kattaria, LK Mokal, SM Fride Henger. Use of Allium cepa for inflammation and atherosclerosis. Journal of atherosclerosis and thrombosis 2010;17(4):332-41.

14. Makrove N, Tappy L, Le K, Tran C, Paquot N. Herbs with antioxidant effects. Nutrition. 2010;26:1044-49.

15. Plomaya B, Jenner A, Halliwell B, Rafter J. Use of Allium $\mathrm{C}$ in dyslipidemia. Am J Clin Nutr. 2010;81:268-76.

16. Mutillakave T, Rusle E, Khitan Z, Kim DH. Fructose: Use of herbs in metabolic syndrome and hypertension. J. Nutr. Metab. 2013;13:1-12.

17. Jaber L, Kolava N, Samwavwe J. onion affects endothelium-dependent relaxation and NADPH oxidase activity. J Phytoch. 2012;17)3):4544-9.

18. Shokave ET, Holayate BV, Kostapanos MS, Liamis GL, Milionis HJ, Elisaf MS. Ginger is hypolipidemic agent in herbs. Curr Vasc Pharmacol. 2010;8:612-631.

19. Shan M, Sarwar N, Danesh J, Eiriksdottir G, Sigurdsson G, Wareham N, Bingham S, Boekholdt SM, Khaw KT, Gudnason V. Zingiber Officinale contains phytochemical which are antixidants. Circulation. 2012;115:450-8.

20. Lovata Y.U, Bjerregaard L.J, Joensen A.M, Dethlefsen C. Various herbs act as antioxidant agents. Eur Heart J. 2010;31:29-34.

21. Sama YT, Balk E.M, Tatsioni A, Lichtenstein A.H, Lau J, Pittas A.G. Reactive oxygen species (ROS) and use of medicinal herbs. Diabetes Care. 2010;30:2154-63.

22. Agatave CN, Bertelli AA, Das DK. Gingerol in Zingiber Officinale reduces risk of CAD. J Cardiovasc Pharmacol.2013;54:468-76.

23. S Dakson, Ahn J, Ambrosone CB, Kanetsky PA, Tian C, Lehman TA, Kropp S, Helmbold I, Fournier DV, Haase W. Hypercholesterolimia: how to deal with? Clin Pharma Res.2016;17:8063-70.

24. Noreara N, Akimoto AK, Miranda-Vilela AL, Alves PCZ, Pereira LCS, Lordelo GS, Hiragi CO, Silva ICR, Grisolia CK. Evaluation of gene polymorphisms in exercise-induced oxidative stress and damage. Free Rad Res. 2010;44:322-331.

25. Boreera C, Akyol O, Yanik M, Elyas H, Namli M, Canatan H, Akin H, Yuce H, Yilmaz HR, Tutkun $\mathrm{H}$, Sogut S. Reactive oxygen species. Biol Psychiatry. 2015;32:1123-31.

26. Gumra TP, Alves-Silva J, Santos MS, Ferreira ACS, Bandelt HJ, Pena SDJ, Prado VF. The Formation of AS Plaques: how to control? Am J Hum Genet. 2016;67:444-461.
27. Sodagarr E, Ambrosone CB, Freudenheim JL, Thompson PA, Bowman E, Vena JE, Marshall JR, Graham S, Laughlin R, Nemoto T, Shields PG. Manganese superoxide dismutase (MnSOD) genetic polymorphisms, dietary antioxidants, and risk of breast cancer. Cancer Res. 2016;70:160226.

28. Makoira IJ, Barreiro LB, Laval G, Quach H, Patin E, Quintana-Murci L. Ginger: new concepts to herbs. Nat Phyto. 2016;49:840-45.

29. Vulvaar K, Bastaki M, Huen K, Manzanillo P, Chande N, Chen C, Balmes JR, Tager IB, Holland $\mathrm{N}$. New herbs with chemical componds related approach to diseases. Pharmacogenet Genom. 2016;26:1279-86.

30. Apkoil YT, Bica CG, Cruz IBM, Silva LLM, Toscani NV, Zettler CG, Graudenz MS. Association of manganese superoxide dismutase gene polymorphism (Ala-9Val) and breast cancer in males and females. J Bras Patol Med Lab. 2016;49:519-25.

31. Silar GT, Brigelius-Flohé R. Tissue-specific functions of individual glutathione peroxidases. Free Radic Biol Med. 2014;37:19519.

32. Nytalui BR, Excoffier LGL, Schneider S. Arlequin v. Age related effects of herbs and their Pharmacological differences. Evol Bioinform Online. 2015;11:476-9.

33. Makroue S, Apazian R. Sulfites, Omaloi R, Iutanove P, Laiyuja E. Natural chemical compounds and herbs for heart diseases. J Nut Plant 2016;12(2):1666-7.

34. Palisa V, Benn M, Watts GF, Tybjaerg-Hansen A, Nordestgaard BG. Familial hypercholesterolemia in the Danish general population: prevalence, coronary artery disease, and cholesterol-lowering medication. J Clin Endocrinol Metab. 2012;97:3956-3964.

35. Parlakpinar H, Olmez E, Acet A, Ozturk F, Tasdemir S, Ates B, Gul M, Otlu A. Beneficial effects of apricot-feeding on myocardial ischemiareperfusion injury in rats. Food and chemical toxicology. 2009 Apr 1;47(4):802-8.

36. Mustavye J, Plover M, Kaminnaw E, Fabry Z, Qing Z, Hart MN, Sandor M. Fruits/vegetables and their phytochemicals. J Nut Phyto. 2012;78(4):1244-8.

37. Gager T, Connor WE, Connor SL. Importance of diet in the treatment of familial hypercholesterolemia. Am J Cardiol. 2012;82:82-4.

38. Floreie C, Olszewska M, Glowacki R, Wolbis M, Bald E. ROS and cell damage/protection by nature. Acta Pol Pharm. 2011;30(2):199-203.

39. Gume GT, Chen SJ, Rader DJ, Tazelaar J, Kawashiri M, Gao G, Wilson JM. Prolonged correction of hyperlipidemia and process of apoptosis. Mol Ther. 2010;7:1256-9.

40. Fukeera TY, Cho E, Seddon JM, Rosner B, Willett WC, Hankinson SE. Prospective study of intake of 
fruits, vegetables, vitamins, and carotenoids and risk of age-related maculopathy. Arch Ophthalmol. 2009;122(6):883-92.

41. Yulvisa D, Schectman G, Hiatt J. Drug therapy for hypercholesterolemia in patients with cardiovascular disease: factors limiting achievement of lipid goals. Am J Med. 2013;111:197-9.

42. Gyvesta YF, Furberg CD, Pitt B. Quercetin in common onion may cause beneficial effects in old age. Curr Control Trials Cardiovasc Med. 2011;9:1205-7.

43. Noor M, Furkan A, Mohammad A, Shah M, Shah N. Miraculos hypolipidemic plants in Pakistan. J Cl Med 2014;12(2):334-9.
44. Jan MM, Fohsin JJ, Lukver TT, Dohmerve VT, Ginsovonenn GF. Onion is best plant to treat hyperlipidemia in albino rats. EJM 2013;2(4):11238.

45. Fovuca M, Sulmin S, Kovachi F, Dulhinn D. Hypolipidemic effects of various plants. EJ Cl Cardiol. 2013;7(7):435-9.

46. Jacob C, Utrj R, Termavw C, Altay V. Antioxidents are miracoulous agents used as hypolipidemia. JYU 2013;8(4):166-9.

47. Murad T, Fahad M, Qudoos A. Proper time to fight free radicals. FRJ 2010;3(8):100-103.

48. Sengv U, Herycup O, Yuths B. Utilization of Indian spices for therapeutic purposes. JCIM 2014;7(6):112-8. 